UDC 316.4

DOI https://doi.org/10.32840/2707-9147.2021.92.3

YU. V. ROMANENKO

Doctor of Sociological Sciences, Professor, Professor at the Department of International Media Communications and Communication Technologies, Institute of International Relations of Taras Shevchenko National University of Kyiv

\title{
SALAZAR AND SALAZARISM IN RECURSION OF CULTURAL IDENTITIES AND VISUAL-ANALYTICAL PORTRAITING: VISUAL-ANALYTICAL AND SOCIO-SYSTEMOLOGICAL REFLEXION
}

The article is devoted to a visual-analytical portrait of Salazar's personality as a recursion of the identities of Portuguese society in connection with Salazarism as a socio-political order. As a result of the analysis, the conclusion was formulated that Salazarism as a system was a clerical-hierocratic traditionalist dictatorship headed by a representative of the intellectual class. The autopoietic nature of Salazarism corresponded to its connection with the history of the country, the legitimate way of coming to power, the content of the cultural, economic and political transformations carried out, the minimization of external influence and autarkism, the Bonapartist strategy of interaction of the regime with various social groups.

It is stated that being a recursion of the highest value identities of Portugal, Salazar in visual-analytical portraiture is identified as a schizoid obsessive-compulsive positive-narcissistic psychopath, the nuclear structure of the character of which was harmoniously realized thanks to the successful inculturation in the Franciscan environment with the subsequent transfer to one of the best cognitive groups country. It is noted that the Salazar regime remained a technocracy until the end of the dictator's days, while Salazar himself allowed elements of professional-corporate crownism. The latter, however, did not accompany the spread of corrupt practices, but was an expression of functional necessity. Assessment of the built corporatist society, taking into account modern criteria, gives grounds to define it as clerical-Catholic, meritocratic-technocratic, with some elements of coercive solidarity and "targeted" repression directed against radical left elements.

Key words: Salazar, salazarism, cultural identities, recursion, Portuguese corporatism, neofunctional theory of society, theory of resource-distributive understanding of narcissism.

Formulation of the problem. The personality of a politician, like any other, from a neo-functionalist point of view, is a recursion of a certain set of his identities, which represent the selectively internalized meanings of cultural systems and the corresponding type of stratification of society. Portuguese society at the beginning of the twentieth century in the set

(C) Yu. V. Romanenko, 2021 
of its identities at the highest levels of value consciousness was clerical and fideistic, and in terms of its socio-professional structure, it slowly entered the group of countries of modernization transition. The presence of a large-scale colonial periphery in Portugal, among other circumstances, also affected the development of Portuguese capitalism due to its conjugation with the militaristic caste and estate-monarchical remnants.

For the sociology of international relations, the study of the personality of a politician in its visual-analytical and socio-systemological aspects seems to be underrepresented both in theoretical sociology, sociology of culture and sociology of personality, and in social psychology. Visual analytics and sociology of visual symbolism, on the one hand, and cultural and social systemology, on the other hand, makes it possible, when studying political leaders, to synthesize the ideas and methodologies of structural neofunctionalism, structuralism, symbolic interactionism and political psychoanalysis.

The presented synthesis makes it possible to identify the marking signs of identities in the empirical components of visually observable body images and behavior of both the personality in general and the personality of the political leader in particular. At the same time, the set of cultural macro-identities of the state, which is revealed in its geocultural, geopolitical, geo-economic positioning, is refracted into the strategy of building relations between the leader of this state and other participants in international relations. This article deals with A. de Oliveira Salazar, whose personality is interesting both in the context of studying the sociology of culture and cultural identities of Portugal, and in the sociology of personality and social psychology.

Salazarism as a new cultural, social and political order defined the image of Portuguese society until the early 70 s of the twentieth century. At the same time, both for the indicated period and after the dictator's departure from life, the connection between his visual-bodily and mental characteristics, cultural identities, non-verbal and communicative components of the way of life and everyday social practices was not a subject for independent research. It also did not seem relevant to explore the relationship between the personality of the dictator and the international positioning of Portugal in the geocultural, geopolitical, geo-economic aspects. The designated subject areas are updated by the author in the presented article.

Analysis of recent research and publications. Publications on the subject of Salazar's personality and Salazarism lend themselves to classification according to the criterion of methodology, breadth / narrowness of the subject field, or belonging to a scientific / journalistic discourse.

According to the first criterion, publications include descriptive-analytical works of positivist and Marxist-oriented authors-historians and political psychoanalysts. The author has not found works that would have been devoted to psychoanalytic portraits of Salazar directly using Freudian, Jungian, Lacanian methodology. At the same time, there is literature on 
other political personalities, presented in the political psychoanalysis of Z. Freud, E. Fromm, W. Reich, G. Lassuela and E.-V. Wilfenstein [1; 6; 16-17; 29-30].

According to the second criterion, these include monographs and scientific articles devoted to the history of Portugal and directly to the biography of Salazar, which is considered in the context of this history (J.-E. Saraiva, A.M. Khazanov, T. Gallagher, O.-T. Almeida) [15; 18-19; 24-25].

According to the third criterion, works on Salazar and Salazarism are classified as scientific or journalistic research, including articles in Russian, English and Portuguese.

The empirical research was carried out by the author on the basis of photographic materials presented in the public domain on the Salazar Portret Study resource [27], as well as other sources of photographic and video materials about the dictator. The algorithm of empirical research is presented in the works of the author of this article and assumes a correlation (qualitative, but not quantitative) identification of cultural, social, psycho-behavioral and bodily-visual personality traits as a recursion of the identities of the cultural and social system. In turn, fundamental for the author of this article are the works of N. Luhmann and his concept of autopoiesis, the development of which, taking into account the ideas of structural functionalism of E. Durkheim, makes it possible to talk about the organistic autopoiesis of dictatorships, which in the social aspect is opposed by the mechanistic autopoiesis of despoties [3; 7-12].

The dictatorship of Salazar, from the moment of her coming to power, was characterized by the organic nature of autopoiesis for a number of reasons: a) due to the correspondence of the social need to overcome poverty and corruption; b) due to the conformity, clerical, fideistic, traditionalist mentality of the Portuguese; c) due to the compliance with the international order of the countries of the fascist axis, which seemed to be the best not for the alliance, but for Portugal; d) due to the minimization of the number of victims of political repression, which, in comparison with the Francoist, Hitlerite and other regimes of the Axis countries, turned out to be minimal.

In the monographs of the author of this article [7-12;20], a six-level algorithm for identifying identities was presented, which, in turn, was integrated with the subsequent study of cultural and social systemology as a version of the neofunctional theory of society. Also methodologically important for the author of the publication is his accepted theory of the resource-distributive understanding of narcissism as a phenomenon that describes the interaction of capitals between social groups and institutions, on the one hand, and an individual, on the other hand. The key idea of the indicated theory is the postulate that the profile of socio-group capital acts as a starting point for the corresponding investment / depositing processes of various types of capital from the side of the corresponding group, both in relation to other social groups and to individuals. 
At the same time, group dispositions have a regulatory effect on both positive and negative narcissistic investments of some groups in relation to others. The state in the context of the defended theory of narcissism acts as a macro-distributor of political capital, which can influence the resource / capital profiles of various groups and, accordingly, different volumes and vectors of investment and deposit by these groups of social, economic, mental, cultural and educational, etc. types of capital.

The purpose of the article is a visual-analytical portrait of Salazar's personality as a recursion of the identities of Portuguese society in connection with Salazarism as a socio-political order.

Statement of the main provisions. The highest value identities of the dictator. In studies on Salazarism and the Portuguese corporate state, the dictator's religious identity is unambiguously associated with his Catholic-oriented family and the rejection of the secular values of the Enlightenment. At the same time, categorical and unambiguous attempts to pass off the declarative denial of the designated values for their political and administrative disregard in the "new order" of Salazar could be considered an incorrect exaggeration. The inclusion of the concepts of utopian socialism in the register of premodern ideologies would be considered the same incorrect exaggeration, although it is these ideologies that bring the enlightenment cult of reason, social freak show to the level of totality, proposing to build sociality on the basis of all-pervading rational regulation.

That this rational regulation is proposed for use with an arrangement of clerical and fideistic arguments should not in the least mislead the critical researcher. So, the unequivocal conclusion regarding the identification of Salazar's religious identity is its assessment as clerical Catholic. Therefore, the corporate state, in such a view, could and should have shared all the problems associated with the pre-reformation period and the counter-reformation "code of honor" of the zealots of the unconditional authority of the papacy.

Salazar was not a hierocratic leader, but his ideological identity was, in fact, an imitation of the hierocracy, both in the rhetorical ornamentation of his speeches and in his political strategy. In one of his speeches, the dictator will put it this way: "Portugal was born in the shadow of the church, and the Catholic religion from the very beginning was the formative element of the nation's soul and the dominant character trait of the Portuguese people" [22].

Portugal, like its bordering Spain, ranked among the counter-Reformation societies of the Iberian Peninsula. In the cultural system of the country, the highest position in the axiosphere was occupied by Catholicism and the Catholic Church with their specific dominance in relation to the political elites. Relations between clerical and political groups were mediated by the military class, which, being incompetent in matters of social management and economics, turned into a kind of puppet in the hands of the hierocracy. This circumstance made possible Salazar's Bonapartism with decorative presidents, a one-party system and a corporate state built on the subordination of capital to labor. 
In one of his first speeches, Salazar demonstrates fideistic categoricalness, assertiveness and steadfastness, combining it with the pragmatic realism shared by the supporters of technocratic state rule.

The dictator proposes "initially to streamline the financial system, for which he insists that $\langle\ldots\rangle$ each ministry undertakes to limit and organize its services within the budget allocated to them by the Ministry of Finance; measures taken by various ministries and having a direct impact on government revenues or expenditures will be preliminarily discussed and adjusted with the Ministry of Finance; the Treasury Department can veto any increase in operating or ordinary expenses, and regulate $\langle\ldots\rangle$ important lending transactions; the Ministry of Finance undertakes to cooperate with various ministries in measures related to cost reduction or revenue collection, so that they can organize their activities, as far as possible, in accordance with uniform criteria" [22].

Salazar casts aside magical illusions about the lightning-fast change in the life of Portuguese society for the better and ends his thought with a Franciscan-Benedictine passage in the style of edifying church sermon: "It is in vain", says the dictator, "to hope that the circumstances of Portuguese life will be miraculously changed with the help of a magic wand. Little would have been achieved if the country had not been willing to make all the necessary sacrifices and accompany me with confidence in my mind and honesty - absolute confidence, but serene, calm, without exaggerated enthusiasm or suppressed despondency. I will illuminate for you the path along which I think to go, about the motives and meaning of everything that is not clear in itself; he will always have at his disposal all the elements necessary to assess the situation" [23].

Catholic religious identity presupposes the impossibility for an ordinary layman to express his own point of view on issues of Holy Scripture, doctrine, or any interpretation without relying on the "superposition" understanding of the authorizing mentor. The flock in Catholicism is not equal to the priesthood in the understanding of the Law, and therefore between the priesthood and non-priesthood is the deepest spiritual and value gap. In Salazar's understanding, the national dictatorship becomes something like the reality of sacred truths, sacred knowledge, in the comprehension of which all who deviate from the principle of the intellectual hierarchy cannot belong to allies and satellites.

Salazar's ideological identity is a recursion of his religious and philosophical identity. First of all, it is anti-communist (and therefore conservative or fascist), anti-trade union (and therefore corporatist), pro-family (and therefore anti-promiscuitarian), anti-Marxist and anti-atheistic (and therefore elitist and clerical), anti-potestary (and therefore legalistic).

The dictator will put it this way: "We are against all internationalisms, against communism, against trade union freethinking, against everything that weakens, divides, dissolves the family, against the class struggle, against the atheists, against force as a source of law. We are against all the great 
heresies of our time $\langle\ldots>$ Our position is anti-parliamentary, anti-democratic, anti-liberal and on its basis we want to build a corporate state" [23].

At the ideological and doctrinal level, his highest value identities were formed by the Anglo-Saxon educational system with its focus on empiricism, the social Catholicism of Leo XIII; clerical-interpreted democracy as a historical fact, independent of the forms of government and compatible with Catholicism, religious freedom and dictatorship; hegemonic theory of the Latin race by S. Morras [4]; Lusitanian integralism ${ }^{1}$ and the asceticism of the Portuguese moralists of the 17th and 18th centuries.

The educational context of the dictator's value identities was laid in Coimbra, about which J.-E. Saraiva writes in his History of Portugal: "They (the thick tomes of the University of Coimbra course) united all the orthodox teaching, that is, the teaching that, under the conditions of the Counter-Reformation, was considered to correspond to the truths of faith. These books, written in Latin, were the basis of education until the time of Pombal, who banned their use. Thus, they were, as it were, the only books for a century and a half, and this made them an essential cause of delay and backwardness: in the 18th century. Portuguese students read textbooks that set out the ideas of the early 17 th century.

On the other hand, the education given by the Jesuits was self-serving education. It represented one of the forms of struggle against heresy and the spirit of the Reformation. After all, the Reformation was a product of mental freedom, the right to think independently, which everyone should have. This is what the teaching system in the collegiums was trying to avoid".

Saraiva puts forward a rather controversial thesis that "criticism always leads to the destruction of dogmas", and not to the strengthening of the latter, making the erroneous conclusion that the Jesuit "education was aimed not at training thought, but at laying the foundations of faith". The latter contradicts the essence of socio-humanitarian education, which, in contrast to natural science, just contributes to the development of free-thinking and divergence of thinking.

However, Saraiva is also mistaken when evaluating the results of such education as contributing to the depth of "faith, but not thought", which reflects his adherence to liberal positivist methodology. If it were not for the depth and height of thought did not correspond to this education, then how did "a large number of educated people emerge from the Jesuit

${ }^{1}$ Lusitanian integralism is a variant of the ideology of integralism that developed in Portugal and whose name is etymologically derived from lat. Lusitania root. The Romans designated the territory of the province with this term, which geographically coincided with the territory of Portugal and the southwest of modern Spain. Lusitanian integralism was created as a doctrinal contraversion and an alternative political strategy in relation to anti-clerical liberalism, socialism, populism and revolution. The French royalist movement Action française, the founders of which put forward a social project of an authoritarian, nationalist, corporatist monarchy during the crisis of the First Portuguese Republic, became the ideological fundamental for Portuguese integralism [34]. 
colleges"? Moreover, the Jesuits followed egalitarian standards, enrolling in the collegium representatives of the nobility, the children of the bourgeois, ordinary people "in whom $<\ldots>$ they saw talents". Noting that "all these people studied Latin, grammar, rhetoric, philosophy", Saraiva believes that his disadvantage was that it (education) did not pay any attention to new sciences and living languages" [15, p. 60].

Salazar himself spoke about the ideology of clerical integralism as follows: "It is obvious that our dictatorial ship is similar to a fascist dictatorship in strengthening power, in a war that it declares on certain democratic principles, in its nationalist character, in its support of the social system. It differs, however, in the repair methods. The fascist dictatorship is leaning towards pagan Caesarism" [28].

The social identity of the dictator was strongly influenced by his parents, whose lifestyle was workaholic. In Portuguese society, they occupied a subgroup intermediate between the employees / managers, which corresponds to the "managerial class", and the peasants.

As T. Gallagher notes, Salazar's parents "came from low-income families that were not involved in subsistence agriculture". Education meant that they could benefit from the innovations that were gradually making their way into the countryside. They quickly had four daughters, and each of them received an education. The eldest, Martha (born 1882), will herself teach arithmetic and grammar at a local elementary school for forty-three years. Salazar, the fifth and last child, was born into a family of hardworking and devout parents. António was the manager of a local estate. He was hired by the Perestrells, who owned significant land in the region that was not intensively cultivated. Their wealth allowed them to own several houses. But it was not enough to earn money on agriculture [24].

The professional identity of the dictator was formed, in fact, as a hybrid, between the priesthood and the cognitive / intelligentsia. This hybridity allowed Salazar to maneuver between pro-monarchist and militaristic social groups, implementing the strategy of Bonopartism and at the same time remaining (until the end of his days) a professor at the University of Coimbra. Salazar allowed himself some of the Cronist practices, placing his university colleagues in key positions in the state apparatus, thereby confirming his reputation as a professor.

Salazar's gender identity, due to the strongly expressed Oedipus complex and his love for his mother, was formed as schizoid-androgynous. As A. Khazanov notes, Maria du Rezgati Salazar - a woman of intelligent and strong character - had a great influence on her son. Later, when he came to power, he consulted with her and said that if she lived longer, he would have to leave government activities and return home, since "she could not live without me" [18, p. 69].

Having idealized the mother as the prototype of the relationship with the future partner, Salazar did not go beyond the (quasi) competition. This corresponded to the manifestation of interest in the female sex mainly in 
the remote aspect, and on the other hand, the preservation of interest in communications with women in public space, which remained, in terms of content, "platonic" and "spiritualistic". Maintaining a quasi-concubinate / quasi-celibate relationship with his housekeeper, Maria de Jesuz Caetano, he raised two adopted daughters who were her nieces.

Identification of bodily-morphological, psycho-behavioral and physiognomic features. In some journalistic publications, one comes across the naming of Salazar's regime as "the dictatorship of an introvert", which reflects a group of temperamental and characterological characteristics of the dictator. The bodily-morphological features of Salazar can be identified according to the typologies of Kretschmer and Sheldon as asthenic and ectomorphic (cerebrotonic), according to Jung's typology - as mental-introverted, according to Pavlov's typology - as left-hemispheric (mental), according to the NLP-typology of modalities - as auditory-digital, according to the pathopsychological typologies of Leonhard - as syntonic-obsessive-demonstrative (hysterical), according to A. Lowen's typology - as schizoid and phallic-narcissistic (obsessive), according to N. McWilliams' typology - as schizoid-obsessive-psychopathic [10, p. 83-199].

Cerebrotonic, schizoid, thought-introverted features were manifested in Salazar in several aspects: rejection of publicity, bodily asceticism, asexuality (which represented the concubine of the Catholic priesthood). In the professional identity of the dictator, the choice of the specialty of jurisprudence and finance also becomes a marker for the left-hemisphere type according to Pavlov, pedantic / stuck type according to Leonhard, schizoid type with accompanying systemic thinking and a high level of abstraction.

M. Rychkov, portraying Salazar in his article, writes the following about him: "The dictator remained faithful to his habits even after coming to power. Salazar was an example of the extreme introvert and avoided any publicity whenever possible. He was not interested in wealth, luxury goods, or the cult of his personality. The Portuguese joked that Salazar would close the curtains in his office at the sight of any street demonstration, even if it was a rally in his support" [13].

F. Nogueira in his book Crises and People describes the multi-layered character of the dictator, emphasizing, first of all, the fanatical maximalism of the psychopath with his characteristic will to power. exercised constant and absolute dominion over your entire being. He drew all his strength from his inner energy (introversion).

Sensitive, nervous, emotional, he, nevertheless, always remained serene, cold, without anger, dispassionate, without haste, without excitement, especially when everyone around him was insecure, confused, disoriented (schizoid psychopathy, which made it possible to combine external coldness into combined with schizoid hypersensitivity).

His clarity never left him, it was for him the way of penetration and knowledge of reality; and his ability for long, slow and careful analysis was never obscured or weakened, from which he drew final conclusions. 
These conclusions he led to a synthesis, systematically mentally supplementing them; and then the feeling was created that he had been pondering over every object or situation for years. He held on and surrendered to everything that surrounded him at every moment; he took care of each problem with exceptional and intense absorption, as if the other did not exist; and he pondered this as if eternity stood before him in order to find the best solution [21].

The combination of psychopathicity and schizoidness may be one of the explanations for the fact that the process of "separation" of the Portuguese colonies itself is protracted in time and Salazar's stubborn unwillingness to give up the "historical lands of Portugal". And all despite the fact that the cost of maintaining the armed forces rose to a state of budget deficit, the number of draft deviators grew, and the small military contingents of the colonial periphery in the 60 s no longer kept the anti-colonial movements under control.

Physionomically, Salazar's profile identifies the nasal type of face according to $\mathrm{K}$. Huter, with a greater dimension of the forehead and nose in comparison with the lips. In the area of the lips, the characteristic tightness and reduction of the labial border is easily identified [27]. The bald patches typical of the schizoid in the frontal part of the forehead according to A. Lowen [2, p. 135-315] are supplemented with "obsessive-compulsive" lips, in which the tendency to filter verbal content, typical of obsessive-compulsive individuals, is complemented by selectively analytical left hemispheric (abstract) thinking [27].

In classical psychoanalysis, a theory of an anal-compulsive nature has been developed in detail, the behavioral leitmotif of which is stinginess, frugality, frugality, diligence, control of instinctual impulses and the regulation of physiological needs by moral norms. The super-strict censorship of compulsive personalities, however, takes on a rationally-rule-like expression, which somewhat reduces its oppressive effect and makes it possible to rationalize the necessary self-restraints.

The real "ode" to the economy of anal-compulsive frugality is Salazar's speech from March 28, 1927, in which he criticizes both the supporters of the economic model of liberalism ("economy of success") and egalitarian despotic communism ("the economy of equating poverty and virtue"). Salazar states that both the first and the second models are erroneous, believing that people were "spoiled" not so much by production as by incorrect, unbalanced consumption. The solution to the problem for him is "the creation of wealth through hard work, the regulation of consumption by the norms of human morality, physical and intellectual development and savings" [18, p. 144-145].

The introversion and self-directionality of the mental system correlates with the shape of the hawk-eagle-shaped nose, which in the character structure corresponds to self-direction and narcissistic self-sufficiency, and in the macro-denomination of Portugal - island isolationism and claims 
to autarkic identity. On the other hand, the size of the nose and the nasal type of face correlate with the scope of the dictator's activity, including his revanchist project to return to Portugal the macro-identity of an influential transcontinental empire.

The elongation of the cartilaginous part of the auricle [27] of Salazar correlates with the dominance of the auditory-digital modality in the perception of information, the prevalence of which corresponds to an interest in abstract-conceptual (doctrinal) knowledge, which is quite consistent with his professional identity (economist and lawyer).

Diagnostic behavior of Salazar also corresponded to hysterical features, which manifested themselves in the observance of conventions, and on the other hand, in political performances, which the dictator accepted with a demonstration purpose for the international encirclement - the states of the fascist axis and the anti-Hitler coalition. Of course, the accomplices of these performances, the leaders of the PIDE (Portuguese security police), were motivated to play along with Salazar's hysteria in the final period of his reign [5].

Some of the hysterical traits manifested themselves during the period of the dictator's formation, when he began to court Julia Perestrolelo, the sixteen-year-old daughter of his godmother. The novel collapsed due to the intervention of parents, who, by attacking, from their point of view, insufficiently worthy son of the governor of their lands in Vimieiro, caused him a narcissistic frustration. The latter allowed the hysterical-exhibitionistic defenses and imagination/sublimation to turn on, thanks to which sexual fantasies were redirected to public female objects and intellectual discussions with them. Salazar showed them both his erudition, charm, and fashionable clothes, which made it possible to compensate for the trauma he had experienced.

As T. Gallagher writes in his work, "he still had a circle of friends, to whom he was an advisor and confidant. Elegantly dressed, he could be seen with his close friend at the theater or at musical evenings. His feelings for these friends fluctuated between friendship and something deeper. They admired this handsome, well-mannered and exquisitely dressed young man because of his professional success, as well as the public position he held. He was a good conversationalist, ironic and witty, but there was nothing superficial about this man. with its considerable emotional depth" [24].

Hysterical personalities turn out to be very sensitive to conventions, and, especially, to maintaining the image necessary for successful social direction. Alden Whitman describes a case when a minister without a hat came to Salazar for an interview. At the end of a conversation with him, Salazar got up and put his hat on the man's head, suppressing the resulting confusion with the remark that "employees look better when they wear hats" [28].

In the described episode, the imitation of Salazar as a representative of the cognitive / salariate of the upper nobility reveals archaic dispositions of his personality, which speaks in favor of the fact that Salazar was not a charismatic leader who acted extraordinary and tried to rebuild the social 
life of the Portuguese on the basis of liberal modernity. Rather, we are talking about a specifically Iberian version of the modernization of clerical monarchies, which, through dictatorships (in particular, General Franco and Salazar), were able to prolong the life of the traditionally monarchical leadership, improving the rational-legal mechanisms of governing society.

However, it is worth noting that more mature schizoid-obsessive defenses (intellectualization / sublimation and moralization / isolation) further contributed to the further establishment of a kind of sexual escapism in Salazar's lifestyle, which corresponded to Catholic concubine. However, this was not a konkubinat in its classical ritual version, however, the external schizoid seclusion of the dictator really reminded him.

Salazar's attitude to Portuguese society in terms of narcissistic investments was profiled so that the largest amount of them fell on symbolic capital (propaganda exaltation of the state in which capital is subordinated to labor, Lusitanism and Lusitanism) while limiting (and subsequently increasing) positive investments in the economic and cultural sector-educational capital.

On the other hand, insignificant negative narcissistic investments in the sphere of political repression, isolated cases of victims of the regime, limited narcissistic racketeering of the dictator in relation to manifestations of political loyalty on the part of the population contributed to moderate tolerance of the malignant aspects of the regime. The limited economic investment of the regime in overcoming poverty and illiteracy was consistent with Salazar's elitist-hierarchical view of the structure of society, in which caring for the elite was more important than overcoming the problems of the lower classes.

Pedantic disciplinarity, the uniformity of everyday life, the tendency to thoroughly delve into the details and details of information in the documents brought, as well as the ways of "reforging" the communists on the island of Tarrafal make it possible to identify Salazar's obsessive and compulsive character structure.

L. Salzman, summarizing the research of Freud and Janet, writes in this regard that "people of obsessive character structure were described by Freud as methodical, stubborn, stingy; others describe them as stubborn, disciplined, perfectionist, punctual, meticulous, stingy, economical, prone to philosophizing and reasoning for minor reasons. Pierre Janet describes such people in this way: rigid, inflexible; they lack adaptive capacity; emphatically conscientious; love order and discipline; persist even in the face of insurmountable obstacles. They are generally reliable, dependable, and people of high standards and ethical values. They are practical, accurate and scrupulous about moral requirements. Under stress or increased stress, these personality traits can be transformed into symptomatic behavior, which can then acquire the character of a ritual" [35].

A. Khazanov adds to this the pattern of ritualistic restraint, typical for obsessive-compulsive personalities, a set of qualities instilled in Salazar by his family, namely: "anatical religiosity, obedient discipline, abstinence, 
chastity, rejection of the new $\langle\ldots>$ abstinence, as well as the desire to scrupulously observe all the petty and strict rules of seminary life". M. de Figueiredo, the future president of the National Assembly and Salazar's seminary comrade, recalled that he received food parcels from home, which he usually shared with Salazar. The rules for seminarians forbade them from entering each other's rooms. Therefore, having first asked permission from the priest, Salazar usually froze at the door of a friend's room, but never crossed its threshold [19].

To summarize the above, Salazar's character structure can be diagnosed as schizoid-obsessive-compulsive positive-narcissistic psychopathy. Psychopathy as a "nuclear" radical for the overwhelming majority of the characters of dictators and despots corresponded to a high level of control of affects due to their sublimation both in intellectual and administrative-political activities. The latter allowed Portuguese corporatism to become the least aggressive, genocidal, xenophobic regime with the best (taking into account the internal state of Portugal) socio-economic results and the least casualties ${ }^{2}$.

Identification of non-verbal and communicative components (gesture, facial expressions, pantomime, taxicab, proximic, gastric, haptic, chronological, oculesic, etc.). The proximal features of Salazar's behavior allow us to confirm the diagnostic hypothesis about the schizoid character. In his youth, Salazar preferred walking the dog to communicating with friends. His sex life was more celibate than traditional family. In public space, Salazar tried to isolate himself from the excess of incentives, appearing in public as little as possible. In Portugal of that period, there was even a joke that even if a crowded meeting in support of Salazar gathered under the house of Salazar, he would most likely draw the curtains of his window.

Some of the peripheral kinesis make it possible to talk about the complex of fusion with the mother that the dictator retained. So, typical for Salazar was the swinging / swinging body movement in a chair, which resembles the well-known motion sickness, which has an autorelaxation and, at the same time, regression meaning for the mental system. Self-wagging,

${ }^{2}$ For forty years, PIDE (Salazars State Security Police $-Y u$. R.) arrested about 15 thousand people. For a country with a population of 7-9 million, this may not be so little. Even taking into account that half of those arrested were soon released without trial, another quarter were acquitted, amnestied or fined, only every fifth was imprisoned for a year and a half and every tenth for two or three. Long-term residents were rare. People who were apolitical were practically not touched, they were engaged only in real opponents of the regime. And they tried to take more of them out of fear than to really repress them. There was no death penalty in Portugal, but about thirty people died in custody [5].

In the Tarrafal concentration camp (Santiago Island, Cape Verde), 37 political prisoners, 34 Portuguese, one from the overseas province of Angola and two from Portuguese Guinea died during the entire period of the dictatorship [36]. Comparison of this statistics with the number of killed and tortured victims of other fascist and, especially, communist regimes (the latter is in the millions) only suggests that the repressions were applied by Salazar's PIDE pointwise and without admitting that cohort-group scale that would be designed for remote intimidation. 
like self-contacting self-hugs, can be preserved in the repertoire of body movements as derivatives of object relations with a covering and protective parental figure, which in the context of the dictator's gender identity corresponds to his description.

On video materials in the public domain [31-33], one can notice a gait pattern characteristic of a schizoid, in which a "dragging" of the legs is identified. The schizoid-ascetic features of Salazar are also noticeable in his tendency, in a later period (50-60s), to put on shabby costumes, which recurs with his religious, philosophical and moral identity, and on the other hand, with the corresponding part of the structure character. Topologically and proximally marking for Salazar, his foreign trips, or rather their absence, are identified. During the entire period of his reign, the only foreign visit of the dictator was a trip to Spain to General Franco [31-32].

Identification of visual symbols in objects of material and spiritual culture, spaces and environments. O.-T. Olmeida offers a visual analysis of the symbolism of the book for reading, which was compulsory for teaching in primary school (in the 3rd grade, according to the author) in Portugal during the dictatorship of Salazar. Citing the work of the English author J. Plamenats and sharing his point of view [26], O.-T. Olmeida finds it very difficult to draw the line between education, information and suggestion / indoctrination. For a researcher, textbooks for primary school classes (on a conscious or unconscious level) reveal the intention "to form the mental structure of a student and prepare him to accept the values and ideologies of one particular group or class, which, as the author concludes, is the essence of ideological processing" [25].

Further, citing the definition of Plamenats, from which it follows that indoctrination should be understood as "teaching beliefs (which the teacher may or may not share) that guarantee the competent performance by people of their social roles and occupations or activities of their choice or the use of opportunities offered by society, or $\langle\ldots\rangle$ loyal behavior in accordance with the standards generally accepted in the community or in the circles they belong to, or ways of thinking and behavior that are desirable for the teacher and correspond to any of his goals" [26, p. 134], O.-T. Almeida supplements this definition with a set of standard teaching techniques through which indoctrination is made possible.

It is about "instilling skills that are generally useful (such as reading and writing)", or "about specific occupations or activities, conveying factual information that is similarly useful", or "presenting theories of historical explanations that are considered preliminary (accepted only as long as they withstand criticism, especially from experts)", which allows "to teach people to follow the usual rules" [25].

Further, the author offers an analysis of a case in which, at the level of visual composition from a school textbook, he explores the ideological indoctrination of the Estado Novo worldview to students. Indoctrination is carried out by the language of visual images, which conveys abstract 
meanings in a form that is digestible for the child's mind. The compilers of the book for reading didactically proceeded from the fact that the thinking of a child in the 3rd grade is at an intermediate stage between the full mastery of concrete and the initial mastery of formal operations. On the whole, judging by their ideas, visual-figurative thinking among students is, nevertheless, the leading one, and therefore it will be convenient to indoctrinate the corresponding ideas of clerical-integralism precisely in visual-figurative expositions.

The image of the page of the Book for reading the 3rd grade in the edition of 1958, the visual composition of which will be analyzed further, we will accompany with our remarks, agreeing or disagreeing with the analytical hypotheses and conclusions of Professor Olmeida [25].

The center of the composition is the coat of arms of Portugal, which is structurally divided into cross-shaped heraldic shields and Moorish castles from the Reconquista period. Christian shields, also called byzantines, are isolated in a white pentagon in relation to the Islamic-Berber periphery, which, however, is integrated into the highest value identities of Portugal. In other words, in one of the axial symbols of macrodentity, which is the state emblem, Portugal declares its belonging to two cultural and value universes - Christian-Catholic and Berber-Islamic [25].

A nursing mother is located directly under the coat of arms, in the lower projection. The artist's projection to depict a nursing mother as the basis of the state is associated with the maternolatric components of Catholicism, which recognizes the cult of the Virgin Mary (Blessed Virgin Mary) as an intermediary figure in the "pantheon" of Christian doctrine. The sacralization of the female-mother image becomes evident against the background of the presence of another spiritual symbol - two white doves sitting at the foot of a woman next to an olive branch, which in the Gospels symbolizes the peace and blessing of God. The second biblical symbol is a bunch of grapes, which symbolizes the abundance and grace of God [25].

The temporal perspective, or historical time-space-turn, is depicted in perspective, where the agrarian landscape is seen: ears of wheat, a church and oxen. These are symbols of everyday peasant labor, which, according to the artist's plan, is depicted as Christocentric. To the right of the nursing woman-mother (and, accordingly, to the left of the observer) is an image of a man with a sickle, to the right of which are the military with the Portuguese flag. However, in the entire composition, male characters are not just numerically dominant.

The woman, presented in the form of a nursing mother, is obviously under their military and religious protection. The founding fathers of knights and hierocracy are represented in the upper projection of the image: King Afonso Henriquez (founder of the nation), Prince Henry, navigator, Nuno Alvarez Pereira (saint and warrior), Camões (poet who immortalized Portuguese discoveries), Vasco da Gama (discoverer sea route to India), Pedro Alvarez Cabral (discoverer of Brazil) [25]. 
The union of the priesthood, the knighthood and the discoverers is visualized quite clearly. The role of the priesthood as a clerical estate of Portuguese society is further strengthened to the right of the observer (and, accordingly, to the left of the woman) by a fragment of a composition with a priest, Negroid proselytes addressed by the priest, and a ship symbolizing colonial adventurism and Portugal's status in the geopolitical order of Europe as thalassic empire. Proselytes are presented in a submissive position due to the kneeling position of the character, covered with white robes, who, judging by the artist's intention, is ready to receive grace [25].

The Monument to the Discoverers and the 25 April Bridge are significant cultural projections of Salazarism. The composition of the monument to the discoverers is presented by the gallery of the patriarchs of Portugal as the first transcontinental empire and maritime superpower. At the head is the figure of Heinrich the Navigator. A. Ryuqua writes about him as the third son of King João I of Avis, brother of King Duarte I of Portugal, Infanta Enrique, who received the title of Duke de Viseu from his father, then ruler of the Algarve and became Grand Master of the Order of Christ in 1420. Having settled in Lagos in 1436, near Cape Sagrish, he united sailors, mathematicians, geographers, astrologers, merchants and doctors around him, became interested in the development of navigation, shipbuilding and began to conduct research expeditions along the African coast. Under his leadership, the island of Madeira was settled, then the Azores, the Portuguese reached Cape Bogador (1434), Cape Verde (1444) and Sierra Leone (1460) [14, p. 378-379].

A passionate explorer, ready to risk his life to discover new continents, he combined the fanaticism of a Christian missionary and a crusader-conqueror, the romantic sublimity of a navigator and conqueror of unknown lands and a banal colonizer and punisher of the peoples of Africa. Under him, a glorious and shameful page began in the history of Portugal as a state-navigator and hunter for Africans with the help of trained dogs.

The monument itself makes it possible to visually represent the social pyramid of Portuguese society both in the frame of imperial identity and the Salazar New Order. Considering that 2 parts of the gallery are located on the east and west sides, taking into account the location, both on the one and on the other, the elite is represented by seven representatives of the reigning dynasty and nobility, fourteen sailors, three Christian missionaries, two scientists, one writer and a historian, one artist, one cartographer, and one woman.

In this case, the "upper stratum" (the first five characters from above) on the eastern side includes four seafarers and one representative of the reigning dynasty, on the western side - one representative of the reigning dynasty, three sailors and one scientist; the "middle stratum" on the eastern side includes four navigators and one writer and historian, on the western side - one cartographer, one chronicler, one artist, one poet and one navigator; the "lower stratum" on the eastern side includes two military men, 
one missionary and two sailors, on the western side, two missionaries, one writer and two representatives of the nobility.

The back-main part of the monument contains the symbolic structure of a cross, inside which there is a sword, which expresses the idea of the subordination of the philosophy of strength and potestarism to the dogmas of the Catholic hierocracy. In this, the pivotal symbols of the monument confirm the right-conservative affiliation of both the regime and the society it built.

Identifying visual symbols in everyday social practices. Alden Whitman, in his article "writes about the dictator's home and his daily activities: "A bachelor, he lived in two and a half floors of a stone house, painted yellow, not far from the São Bento Palace, the seat of government in Lisbon. He was connected by a passage to the church, where he often went to pray. Behind the white walls of the house, 10 feet high, was a garden of pines, palms and flowers. His only known hobby was taking care of flowers". In addition to the housekeeper, Salazar lived in a house with two daughters, Maria Antonia and Mikas, whom he adopted as infants over 20 years ago. Government duties occupied him 12 hours a day or more, even when he was in his late 70s. Describing his office in 1961, Acheson wrote: "The medium-sized room was lined on three sides with books and paintings above them, as well as a writing desk and upholstered leather chairs. I saw no phone, no files, no papers on the table, no humorous figurines and framed mottos that Presidents Roosevelt and Truman admired. Everything was informal, convenient, simple and unpretentious" [28].

Salazar displayed the typical pedantry of the working day, characteristic of the disciplinary-compulsive type of character, which was culturally processed in the Jesuit environment. His working day "began with breakfast at $8.30 \mathrm{am}$, during which he read the newspapers. Then he worked in his office until $2 \mathrm{pm}$. Between $2 \mathrm{pm}$ and $4 \mathrm{pm}$ he had a 15 minute lunch, took a walk and received visitors. From 16 to 18 , he rested and walked again in the park of his residence in São Bento. From 6 pm to $9 \mathrm{pm}$ he again worked in his office. After that he had a light supper and returned to work until midnight" [28].

A. Khazanov points out that Salazar's desk "was filled with neatly folded piles of official documents and correspondence". It cannot be denied that, in spite of his clerical conservatism, Salazar was initially seduced by the image of Mussolini, whose photo was on the right, and which he himself later replaced with "a photo of the Pope". To confirm the correctness of the diagnosis of a schizoid character, the researcher fixes the bachelorhood and asceticism of Salazar, who, plus everything, "did not use steam heating", although "he was not an absolute teetotaler and usually drank a glass of wine from the Dan region", where this "never smoked". He worked in his office, wrapped in a carpet, and in order to further protect himself from the cold Lissabon winter, he did not take off his coat [18, p. 104].

Conclusions. Salazarism as a system was a clerical-hierocratic traditionalist dictatorship headed by a representative of the intellectual class. 
The autopoietic nature of Salazarism corresponded to its connection with the history of the country, the legitimate way of coming to power, the content of the cultural, economic and political transformations carried out, the minimization of external influence and autarkism, the Bonapartist strategy of interaction of the regime with various social groups. Being a recursion of the highest value identities of Portugal, Salazar in visual-analytical portraits is identified as a schizoid obsessive-compulsive positive-narcissistic psychopath, whose core character structure was harmoniously realized thanks to a successful inculturation in the Franciscan environment with the subsequent transfer to a subgroup of the country's cognitive university. Until the end of the dictator's days, Salazar's regime remained a professocracy, while Salazar himself allowed elements of professional-corporate crownism. The latter, however, did not accompany the spread of corrupt practices, but was an expression of functional necessity. Assessment of the built corporatist society, taking into account modern criteria, gives grounds to define it as clerical-Catholic, meritocratic-technocratic, with some elements of coercive solidarity and "targeted" repression directed against radical left elements.

\section{Bibliography}

1. Лассуэлл Г. Психопатология и политика : монография / пер. с англ. Т. Самсоновой, Н. Коротковой. Москва : Издательство РАГС, 2005. 352 с.

2. Лоуэн А. Физическая динамика структуры характера. Москва : Корвет, 2016. $318 \mathrm{c}$.

3. Луман Н. Общество как социальная система / пер. с нем. А. Антоновского. Москва : Логос, 2004. 232 с.

4. Моррас Ш. Будущее интеллигенции / пер. с фр. А. Руткевич. Москва : Праксис, 2003. $156 \mathrm{c.}$

5. Парни из ПИДЕ. URL: https://vkrizis.ru/analiz/parni-pide/ (дата обращения: 09.09.2021).

6. Райх В. Психология масс и фашизм. Москва : Университетская книга, 1997. $379 \mathrm{c}$.

7. Романенко Ю., Яковенко А. Основи візуальної аналітики та соціології візуального символізму. Київ : Вид-во ДУІКТ, 2008. 318 с.

8. Романенко Ю., Яковенко А., Огаренко Т. Основи візуальної аналітики та соціології візуального символізму в міжкультурних комунікаціях. Київ : Вид-во ДУІКТ, 2009. 275 с.

9. Романенко Ю., Скідін Л. Механізми символічної інтеракції в комунікаціях, політиці, мистецтві: візуально-аналітичний та соціосимволічний аспекти. Київ : ДУІКТ, 2011. $380 \mathrm{c.}$

10. Романенко Ю., Святненко І., Зінченко А. Візуалізації в медійно-комунікаційному просторі: соціо-системологічний підхід. Київ : Видавничо-поліграфічний центр Інституту міжнародних відносин, 2014. $458 \mathrm{c}$.

11. Романенко Ю. Осевые символы идентичности в государственной атрибутике : монография. Киев : Меркьюри-Подолье, 2017. 296 с. 
12. Романенко Ю. Основи візуальної аналітики і прогностики : навчально-методичний посібник для проведення лекційних та семінарських зайнять, організації самостійної роботи для студентів відділення «Міжнародні комунікації». Київ : Меркьюрі-Поділля, 2019. 327 с.

13. Рычков М. Диктатура интроверта: путь Антониу Салазара от надежды Португалии до правителя, пытающегося удержать власть из постели. URL: https:// tjournal.ru/stories/150363-diktatura-introverta-put-antoniu-salazara-ot-nadezhdyportugalii-do-pravitelya-pytayushchegosya-uderzhat-vlast-iz-posteli (дата обращения: 27.09.2021).

14. Рюкуа А. Средневековая Испания. Москва : Вече, 2014. 384 с.

15. Сарайва Ж.-Э. История Португалии. URL: https://my-books.me/books/ istoricheskaya-proza/page-60-91711-zhoze-ermanu-saraiva-istoriya-portugalii.html (дата обращения: 07.10.2021).

16. Фрейд 3., Буллит У. Томас Вудро Вильсон, 28-й президент США. Психологическое исследование. Москва : Канон+РООИ «Реабилитация», 2016. 336 с.

17. Фромм Э. Анатомия человеческой деструктивности. Москва : Биг-Пресс, 2012.488 c.

18. Хазанов А. Португалия и ее империя в эпоху Салазара и Каэтано. Москва : Институт востоковедения РАН, 2015. 308 с.

19. Хазанов А. Салазар: 40 лет диктатуры в Португалии. URL: http://istorja.ru/ forums/topic/2124-antoniu-di-oliveyra-salazar/ (дата обращения: 07.10.2021).

20. Этническая идентичность: социосистемологическое измерение геополитики : монография / Я. Зоська, Ю. Медведева, Ю. Романенко, И. Святненко, Н. Туленков, Е. Хомерики ; ред.-коорд. Ю. Романенко. Киев : Меркьюри-Подолье, 2016. 369 c.

21. $126^{\circ}$ aniversário de nascimento do prof. doutor António de Oliveira Salazar. URL: https://oliveirasalazar.org/download/documentos/126\%C2\%BA $\% 20$ aniv. $\% 20 \mathrm{de} \%$ 20nasc. $\% 20$ do\%20Prof.\%20Oliveira\%20Salazar C6AE7D68-F390-436C-A6C5E56C4E5B647D.pdf (date of access: 07.10.2021).

22. Pensamentos e frases emblemáticas. Salazar O Obreiro da Patria. URL: https:// oliveirasalazar.org/frases.asp (date of access: 07.10.2021).

23. Discursos. Salazar O Obreiro da Patria. URL: http://oliveirasalazar.org/ discursos.asp. (date of access: 07.10.2021).

24. Gallagher T. Salazar: The Dictator Who Refused to Die. URL: https://dokumen. pub/salazar-the-dictator-who-refused-to-die-9781787383883.html (date of access: 07.10.2021).

25. Almeida O.-T. Values and ideology in the school curriculum: a case study. URL: https://visualizingportugal.squarespace.com/almeida (date of access: 07.10.2021).

26. Plamenatz J. Ideology. London : MacMillan, 1971. 148 p.

27. Salazar portrait study. URL: http://visualizingportugal.com/sal-vn1-2-portraitstudy (date of access: 20.10.2021).

28. Whitman A. Antonio Salazar: A Quiet Autocrat Who Held Power in Portugal for 40 Years. URL: https:/www.nytimes.com/1970/07/28/archives/antonio-salazar-a-quietautocrat-who-held-power-in-portugal-for-40.html (date of access: 20.10.2021)

29. Wolfenstein E. The Revolutionary Personality. Princeton, New Jersey : Princeton University Press, 1967. 346 p.

30. Wolfenstein E. Personality and Politics. Los Angeles : Dickenson Press, 1969. 300 p. 
31. Португальский Путин: вставание с колен, стабильность и нечестные выборы. URL: https://www.youtube.com/watch? $\mathrm{v}=\mathrm{pWb}$ inyCafA\& $\mathrm{ab}$ channel $=\% \mathrm{D} 0$ $\% 9 \mathrm{C} \% \mathrm{D} 0 \% \mathrm{~B} 0 \% \mathrm{D} 0 \% \mathrm{BA} \% \mathrm{D} 1 \% 81 \% \mathrm{D} 0 \% \mathrm{~B} 8 \% \mathrm{D} 0 \% \mathrm{BC} \% \mathrm{D} 0 \% 9 \mathrm{~A} \% \mathrm{D} 0 \% \mathrm{~B} 0 \% \mathrm{D} 1 \% 86$ (дата обращения: 20.10.2021).

32. Антоніу де Олівейра Салазар. Диктатори. URL: https://www.youtube.com/ watch? $\mathrm{v}=\mathrm{uYqnoc} 5 \mathrm{WSys} \& \mathrm{ab}$ channel $=24 \% \mathrm{D} 0 \% 9 \mathrm{~A} \% \mathrm{D} 0 \% \mathrm{~B} 0 \% \mathrm{D} 0 \% \mathrm{BD} \% \mathrm{D} 0 \% \mathrm{~B} 0 \% \mathrm{D} 0$ \%ВВ (дата звернення: 20.10.2021).

33. Жертвы Салазара. Отношение к жертвам и палачам в демократической Португалии. URL: https://www.youtube.com/watch?v=9UvgyIkkMj4\&t=466s\&ab channel $=\% \mathrm{D} 0 \% 9 \mathrm{C} \% \mathrm{D} 0 \% \mathrm{~B} 5 \% \mathrm{D} 0 \% \mathrm{~B} 6 \% \mathrm{D} 0 \% \mathrm{~B} 4 \% \mathrm{D} 1 \% 83 \% \mathrm{D} 0 \% \mathrm{BD} \% \mathrm{D} 0 \% \mathrm{~B} 0 \% \mathrm{D} 1 \%$ $80 \% \mathrm{D} 0 \% \mathrm{BE} \% \mathrm{D} 0 \% \mathrm{~B} 4 \% \mathrm{D} 0 \% \mathrm{BD} \% \mathrm{D} 1 \% 8 \mathrm{~B} \% \mathrm{D} 0 \% \mathrm{~B} 9 \% \mathrm{D} 0 \% \mathrm{C} \% \mathrm{D} 0 \% \mathrm{~B} 5 \% \mathrm{D} 0 \% \mathrm{BC} \%$ $\mathrm{D} 0 \% \mathrm{BE} \% \mathrm{D} 1 \% 80 \% \mathrm{D} 0 \% \mathrm{~B} 8 \% \mathrm{D} 0 \% \mathrm{~B} 0 \% \mathrm{D} 0 \% \mathrm{BB}$ (дата обращения: 20.10.2021).

34. Integralismo Lusitano. URL: https://hmong.ru/wiki/Integralismo_Lusitano (date of access: 20.10.2021).

35. Salzman L. Treatment of the obsessive personality. New York : Jason Aronson, 1980.528 p.

36. Концентрационный лагерь Таррафал. URL: https://hmong.ru/wiki/Tarrafal camp\#title (дата обращения: 20.10.2021).

Романенко Ю. В. Салазар і салазаризм у рекурсії культурних ідентичностей та візуально-аналітичному портретуванні: візуальноаналітична й соціосистемологічна рефлексія

Статтю присвячено візуально-аналітичному портретуванню особистості Салазара як рекурсіі ідентичностей португальського суспільства у зв 'язку із салазаризмом як соціально-політичним порядком. Унаслідок проведеного аналізу сформульовано висновок про те, щзо салазаризм як система являв собою клерикально-ієрократичну традиціоналістську диктатуру, очолювану представником інтелектуального класу. Аутопоезійності салазаризму відповідали його зв 'язок з історією краӥни, легітимний спосіб приходу до влади, зміст здійснених культурних, економічних і політичних трансформацій, мінімізація зовнішнього впливу та автаркічність, бонапартистська стратегія взаємодії режиму з різними сочіальними групами.

Констатовано, що Салазар, будучи рекурсією вищих иіннісних ідентичностей Португалії, у візуально-аналітичному портретуванні ідентифікується як иизоїдний обсесивно-компульсивний позитивно-нарцисичний психопат, ядерна структура характеру якого була гармонійно реалізована завдяки успішній інкультурачії у францискканському середовищі з подальшим переведенням в одну з найкращих пізнавальних груп країни. Зазначено, шчо режим Салазара до кіния днів диктатора залишався технократією за умови допущення самим Салазаром елементів професійно-корпоративного кронізму. Однак останній не супроводжував поширення корупиійних практик, а був вираженням функиіональної необхідності. Оцінка побудованого корпоративістського суспільства з урахуванням сучасних критерїв дає підставу визначити його як клерикально-католицьке, меритократично-технократичне з окремими елементами примусової солідарності та «таргетованої» репресії, спрямованої проти ліворадикальних елементів.

Ключові слова: Салазар, салазаризм, культурні ідентичності, рекурсія, португальський корпоративізм, неофункціоналістська теорія суспільства, теорія ресурсно-дистрибутивного розуміння нарциисизму. 